ORIGINAL INVISTTIATION

Faina Schwartz $\cdot$ Rachael Neve $\cdot$ Robert Eisenman

Manfred Gessler · Gail Bruns

\title{
A WAGR region gene between PAX-6 and FSHB expressed in fetal brain
}

Received: 7 January 1994 / Revised: 19 May 1994

\begin{abstract}
Developmental delay or mental retardation is a frequent component of multi-system anomaly syndromes associated with chromosomal deletions. Isolation of genes involved in the mental dysfunction in these disorders should define loci important in brain formation or function. We have identified a highly conserved locus in the distal part of $11 \mathrm{pl} 3$ that is prominently expressed in fetal brain. Minimal expression is observed in a number of other fetal tissues. The gene maps distal to PAX -6 but proximal to the loci for brain-derived neurotrophic factor (BDNF) and the beta subunit of follicle stimulating hormone (FSHB), within a region previously implicated in the mental retardation component of some WAGR syndrome patients. Within fetal brain, the corresponding transcript is prominent in frontal, motor and primary visual cortex as well as in the caudate-putamen. The characteristics of this gene, including the striking evolutionary conservation at the locus, suggest that the encoded protein may function in brain development.
\end{abstract}

\section{Introduction}

Contiguous gene syndromes are a group of developmental disorders associated with deletions of specific chromosomal regions (Schmickel 1986). Isolation of the genes underlying the multiple phenotypic features of these syndromes should define sets of loci important in develop-

F. Schwartz $\cdot$ R. Eisenman - G. Bruns (区) Genetics Division, Children's Hospital, 300 Longwood Ave. and Department of Pediatrics, Harvard Medical School, Boston, MA 02115, USA

R. Neve

Molecular Neurogenetics Laboratory,

McLean Hospital and Department of Genetics, Harvard Medical School, Boston, MA

M. Gessler

Theodor-Boveri-Institut für Biowissenschaften,

Physiologische Chemie I, Wurzburg, Germany ment of a number of organ systems. The first of the contiguous gene syndromes identified was the WAGR complex (Wilms tumor, aniridia, genitourinary anomalies and mental retardation) with the characteristic deletion of 11 pl3 (Riccardi et al. 1978; Francke et al. 1979). This chromosomal region encodes loci important for development of the kidney, male genitourinary system, eye and brain as well as other genes of as yet unknown function. Although the WT-1 and aniridia genes have been isolated (Call et al. 1990; Gessler et al. 1990; Bonetta et al. 1990; Ton et al. 1991), the number and characteristics of genes underlying the mental retardation component of the WAGR syndrome remain largely unknown.

In this report we describe a highly conserved locus in the distal part of the WAGR deletion region that identifies a transcript prominent in fetal brain. This locus maps proximal to the genes for brain derived neurotrophic factor (BDNF; Hanson et al. 1992) and the beta subunit of follicle stimulating hormone (FSHB) within a deletion subinterval previously implicated in part of the mental retardation component of the WAGR syndrome.

\section{Materials and methods}

Isolation of D11S302

Identification of human recombinants in the complete Hindlll digest Charon 21 A library of flow-sorted chromosomes 11 from the National Gene Library Project (LLIINSOI) and mapping of inserts with mini-panels of DNAs from somatic cell hybrids has been described (Gessler et al. 1989). In addition to human lymphoblastoid DNA and DNA from E36 Chinese hamster cells, the somatic cell hybrid panels included DNAs from three to seven hybrids that provided definitive or provisional assignment to chromosome 11 as well as DNA from one or two hybrids containing chromosome 11 homologues with WAGR region chromosomal deletions (Gessler et al 1989). Most mini-panels included DNA from the humanmouse hybrid RJK34, which contained the derivative chromosome 11 pter-q23::Xq26-qter (Scott et al. 1979) together with three other human chromosomes.

Phage inserts that mapped within the WAGR deletion region were subcloned into pUC19 and unique sequence subfragments identified (Gessler et al. 1989). D1 IS302 (defined by probe 239P) 
was subcloned in pUC19 as a $1.1 \mathrm{~kb}$ Pst $/$ HindIII end fragment of the 4.3-kb HindIII insert of phage 239.

\section{Genomic DNA analysis}

DNA isolation from lymphoblastoid and hybrid cell lines has been described (Gessler et al. 1989). Mouse, bovine and chicken DNAs were purchased from Clontech Laboratories. DNA concentrations were measured spectrofluorometrically (Brunk et al. 1979). For genomic and cross-species hybridization blots, 6-10 $\mu \mathrm{g}$ of EcoRI- or HindIII-digested DNA were loaded per lane. For somatic cell hybrid panels, 9-10 $\mu \mathrm{g}$ of digested hybrid DNA was used per lane. Electrophoresis was carried out in $0.8 \%$ agarose gels in TBE buffer and DNA transferred to GeneScreen, GeneScreen Plus, or nitrocellulose.

The hybridization and washing conditions for blots on GeneScreen or Gene Screen Plus membranes have been described (Gessler et al. 1989). Nitrocellulose membranes were hybridized at $42^{\circ} \mathrm{C}$ in $50 \%$ formamide, $4 \times \mathrm{SSC}, 0.05 \mathrm{M}$ sodium phosphate, $\mathrm{pH}$ $6.8,10 \times$ Denhardt's $(0.2 \%$ ficoll, $0.2 \%$ polyvinylpyrrolidone, $0.2 \%$ bovine serum albumin, final concentration), $8 \%(\mathrm{w} / \mathrm{v}) \mathrm{dex}$ tran sulfate, $0.1 \%$ SDS and $25 \mu \mathrm{g} / \mathrm{ml}$ denatured salmon sperm DNA. Filters were washed at room temperature (RT) and at $55^{\circ} \mathrm{C}$ for $30 \mathrm{~min}$ in $0.2 \times \mathrm{SSC}, 0.1 \%$ SDS prior to exposure to XAR-5 film at $-80^{\circ} \mathrm{C}$ with an intensifying screen. Cross-species conservation blots were hybridized at $40^{\circ} \mathrm{C}-41^{\circ} \mathrm{C}$ in $40 \%$ formamide, $6 \times$ SSC and washed at $51^{\circ} \mathrm{C}-53^{\circ} \mathrm{C}$ in $0.4-0.5 \times$ SSC, $0.1 \%$ SDS. Hy bridization probes were isolated from $0.5 \%$ LMT agarose gels in TAE buffer and labelled by random hexamer priming (Feinberg and Vogelstein 1984).

\section{cDNA library screening and analysis of clones}

One million pfu of a human fetal brain cDNA library in lambda gt10 prepared with RNA from a 19-week gestation fetus (Feener et al. 1989) (generously provided by Dr. L.M. Kunkel) were screened on duplicate nitrocellulose filters (Schleicher and Schull) with radiolabelled genomic fragment D11S302. Hybridization was carried out at $42^{\circ} \mathrm{C}$ in $50 \%$ formamide, $10 \times$ Denhardt's, $6 \times \mathrm{SSC}$, $0.05 \mathrm{M}$ sodium phosphate, $\mathrm{pH} 7.2,0.1 \%$ SDS and $25 \mu \mathrm{g} / \mathrm{ml}$ of denatured salmon sperm DNA. Filters were washed with $2 \times$ SSC, $0.1 \%$ SDS at RT and at $55^{\circ} \mathrm{C}$ with $0.2 \times \mathrm{SSC}, 0.1 \%$ SDS.

Phage DNA was prepared by the method of Helms et al. (1985). EcoRI-digested DNA was separated on $0.8 \%$ agarose gels in TBE and insert fragment sizes estimated with lambda size markers. The DNAs were transferred to Gene Screen Plus and hybridized with radiolabelled DI1S302 (Church and Gilbert 1984). EcoRI fragments from each phage were subcloned into pBluescript II-SK vector (Stratagene). Restriction endonuclease mapping of inserts was carried out by established protocols (Sambrook et al. 1989).

\section{RNA analysis}

RNA was obtained from brain tissue and other organs of fetal abortuses. RNA was isolated from each brain region by the guanidinium thiocyanate procedure (Chirgwin et al. 1979) as modified by Neve et al. (1986). The amount of RNA purified from each region was determined by OD 260; OD-260/280 ratios were also determined to confirm uniformity of this ratio among the samples. Ten micrograms of total RNA from each brain region was subjected to electrophoresis on agarose/formaldehyde gels, transferred to Biotrans membrane (ICN), and hybridized with radiolabelled probe (Neve et al. 1986). The blots were exposed to Kodak X-Omat AR film for 1-3 days. Northern blots of RNAs from other fetal tissues were similarly prepared. Beta actin and cyclophilin cDNA probes were used as hybridization controls for the Northern blots.

\section{Results}

D11S302: a highly conserved genomic locus

During development of a WAGR region specific probe bank (Gessler et al. 1989), approximately 450 chromosome 11 derived phage clones were isolated from the LL11NSO1 HindIII digest Charon 21A library of flowsorted chromosomes 11 from the National Gene Library Project. About one-third of the WAGR deletion region (distal 11p12-mid 11p14) probes from this library identified related sequences in rodent DNA (Gessler et al. 1989). All but 2 of these map within the 11 pl3 Giemsa light band.

The hybridization pattern of one highly conserved, randomly isolated genomic clone (designated 239P or D11S302) is shown in Fig. 1. The probe, a 1.1-kb end fragment from an $\sim 4.3-\mathrm{kb}$ genomic HindIII fragment, identifies a single component in EcoRI-digested human DNA, which segregated solely with chromosome 11 in the hybrids tested. The lack of hybridization in lanes 7 and 8 positions D11S302 within the overlap area of the NW and MJ WAGR deletions, a region of at least 8.5 megabases. The variation in mobility of the intensely cross-hybridizing hamster component (lanes 7 and 8) likely reflects an EcoRI restriction fragment length polymorphism (RFLP) in the hamster parental cell line of the hybrids. The segregation of D11S302 was completely concordant with chromosome 11 in National Institute of General Medical Sciences (NIGMS) human-rodent somatic cell hybrid panel no.1. Discordancy fractions for all other chromosomes ranged from 0.33 to 0.67 (not shown). Physical mapping of the WAGR deletion region by pulse field gel electrophoresis (Gessler and Bruns 1989a) had positioned D11S302 at the centromeric end of a 3100-kb NotI fragment that includes the more telomeric FSHB locus. D1 1 S302 is located $\sim 1400 \mathrm{~kb}$ telomeric to the aniridia locus, PAX-6, and $2100 \mathrm{~kb}$ telomeric to the WT1 locus (Fig. 2). D11S302 and FSHB are likely separated by no more than $300-400 \mathrm{~kb}$. Each locus identifies distinct SfiI and SalI fragments: however, they share large NotI and

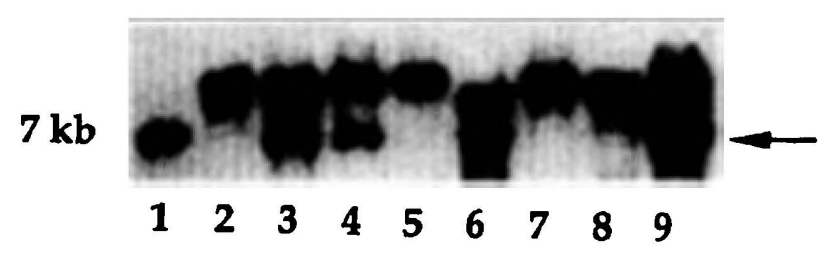

Fig. 1 D1 IS302 maps within the WAGR deletion. The EcoRI-digested DNAs are from: lane $1 \mathrm{XY}$ lymphoblasts; lane 2 Chinese hamster E36 cells; lanes 3-5,7-9 human-Chinese hamster hybrids; lane 6 a human-mouse hybrid with a derl1 chromosome (1 lpterq23::Xq26-qter). The DNAs in lanes 7 and 8 are from hybrid cells that contain chromosome 11 homologues with the NW and MJ WAGR deletions, respectively. Chromosome 11 is the only human chromosome shared by the hybrids in lanes 3,4,6 and 9. The arrow indicates the human genomic component 


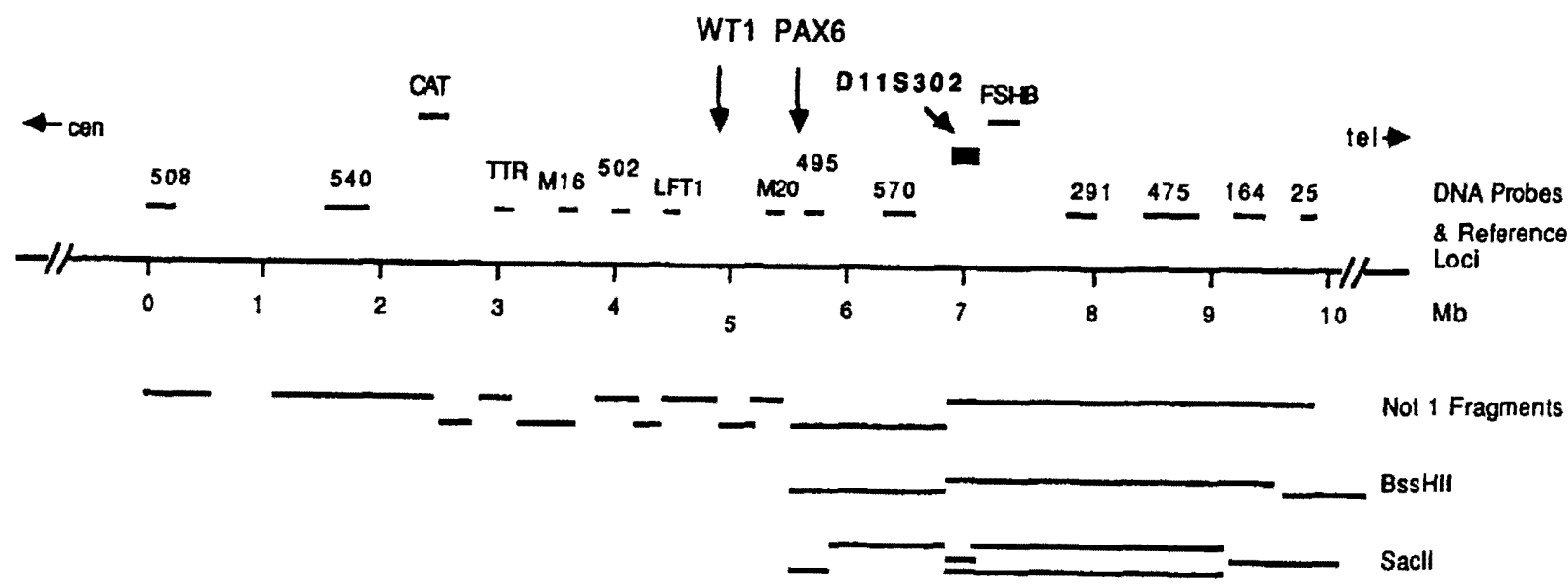

\$1"

WTo

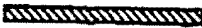

\$M

Fig. 2 Schematic map of the WAGR deletion region. Positions of reference loci $C A T, F S H B, W T I$ and $P A X-6$ and other WAGR region DNA probes (Gessler and Bruns 1989a) are indicated. The solid box marks the position of D11S302 (probe 239P). NotI fragment locations and approximate sizes are indicated for the entire
GM7736

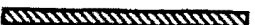

GM6803

$\mathrm{CL}$

region (Gessler and Bruns 1989a); BssHIl and Sacll fragments, for the telomeric region beginning at D13S310. Boundaries of the CL. GM8785, GM6803 and GM7736 deletions are indicated (Gessler et al. 1989; Gessler and Bruns 1989b). Phenotypes associated with the deletions are described in the text

A
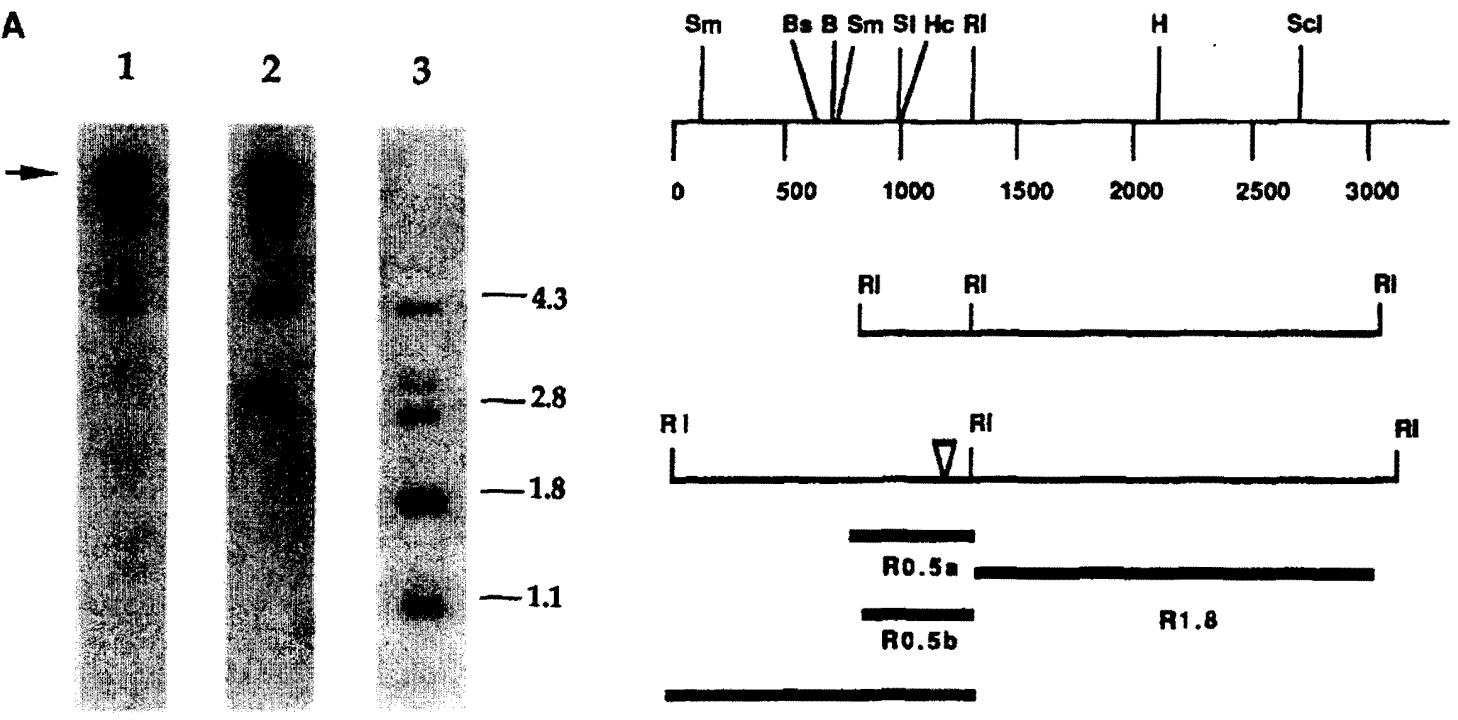

C239P.A

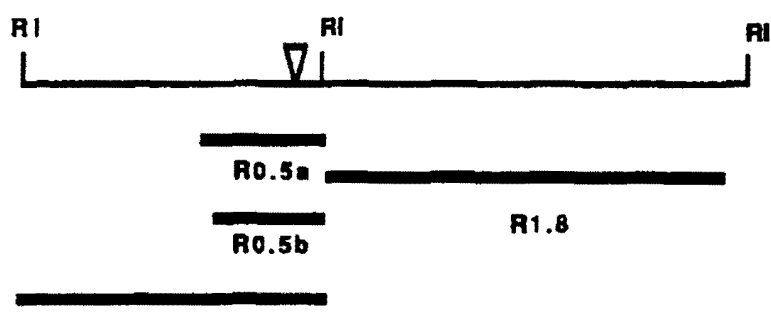

C239P.E

Fig. 3 A Hybridization pattern of D 11 \$ 302 derived cDNA clones. Panels 1,2 Genomic components of $-4.3 \mathrm{~kb}$ and $21 \mathrm{~kb}$ are identified by both the $0.5-\mathrm{kb} E c o$ RI fragment (R0.5a) from clone c239PA (panel 2) and the 1.3-kb EcoRI fragment (RI.3) from clone c239P-B (panel I) in HindIII digested DNA. The longer probe detects an additional large HindIII fragment. Panel 3 Multiple HindIII fragments of $1.1 \mathrm{~kb}$ to $4.3 \mathrm{~kb}$ are defined by the $1.8 \mathrm{~kb}$
EcoRI fragment (R1.8) from c239P-A. Fragment sizes are indicated. B Diagram of the cDNA clones. The restriction map is shown at the top. Orientation of the EcoRI fragments within phage inserts was determined by restriction mapping. Solid bars indicate subfragments used as probes. $B$ BamHI; $B$ s BssHII; $H$ Hindlli; $H c$ HinclI; $R$ EcoRI; ScI SacI: SI Sall; Sm Smal 


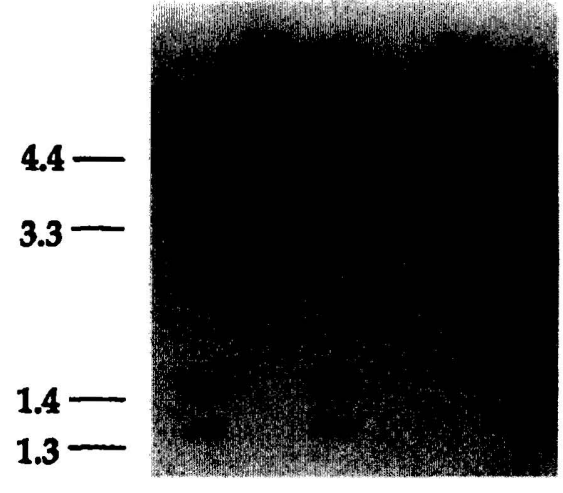

123

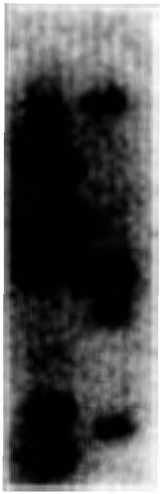

67

Fig. 4 Genomic fragments identified by the R1.8 cDNA subclone from c239P-B map within the MJ deletion. The EcoRI-digested DNAs are: lane I XY lymphoblasts; lane 2 Chinese hamster E36 cells; lane 3 human-hamster hybrid G156E5 with chromosome 11 and 4 other chromosomes; lane 4 human-hamster hybrid (G157A6) with the MJ deletion; lane 5 human-mouse hybrid with the der 11 chromosome. Sizes of human components are indicated. The presence of the 3.3-, 1.4- and 1.3-kb human fragments in lanes 3 and 5 , together with their absence in lane 4, establishes a chromosome 11 assignment within the MJ WAGR deletion. The additional bands in lane 5 are murine components. For comparison, the relative mobilities of human (lane 6) and murine (lane 7 EcoRI components identified by $R 1.8$ are shown. The $R 1.8$ probe from c239P-B is very slightly longer at the 3 ' end than R1.8 from c239P-A (see Fig. 3B)

Fig. 5A Expression pattern in fetal tissues (20 weeks gestation). The total RNAs are: lane 1 spleen; lane 2 thymus; lane 3 skeletal muscle; lane 4 kidney; lane 5 liver; lane 6 lung; lane 7 small intestine; lane 8 heart; lane 9 adrenal gland; lane 10 brain cortex. B Expression in fetal and adult cortex. Lane 1 adult cortex from a 74-year-old individual; lane 2 fetal cortex (19 weeks); lane 3 poly ${ }^{+}$RNA from fetal cortex. Total RNA was used in lanes $I$ and 2 . The 1.8-kb EcoRI fragment was used as probe. The hybridization of a beta actin cDNA control probe to the RNAs in A and of a cyclophilin cDNA probe to the RNAs in B is shown below each lane. Hybridization of the blot in $\mathbf{A}$ with a glyceraldehyde-3phosphate dehydrogenase cDNA probe (not shown) indicated that the amount of heart RNA in lane 8 was comparable to the other samples whereas the amount of adrenal gland RNA in lane 9 was approximately $30 \%$ less than that in surrounding lanes. The under representation of beta actin sequences in fetal heart RNA has been consistently observed by R. Neve (unpublished observations)
BssHII fragments as well as SacII and NruI partial digest fragments (Gessler and Bruns 1989a). The apparent clustering of NotI, BssHII and SacII sites just centromeric to D11S302 suggests that this locus may be near an HTF island.

Gene dosage analysis of DNAs from patients with WAGR region rearrangements (Gessler et al. 1989) located D11S302 in an interval between the distal breakpoints of the C.L. and GM8785 deletions (Fig. 2). C.L. had Wilms tumor and aniridia but average intelligence (Russell and Weisskopf 1986), whereas GM8785 cells were derived from a 5-month-old child with aniridia and developmental delay. Both GM6803 and GM7736 derive from patients with mental retardation, aniridia and genitourinary anomalies. The proximal boundary of the C.L. deletion is more centromeric than those in GM8785, GM6803, GM7736 and other WAGR/AGR patients with mental retardation (Gessler et al. 1989; Gessler and Bruns 1989b; Junien and McBride, 1989) but it does not extend as far on the telomeric side (Fig. 2). The deletion in a second patient with Wilms tumor and aniridia but normal intelligence also terminates just proximal to D11S302 (Junien and McBride 1989; G. Bruns et al., unpublished observations). It had been proposed, therefore, that an area between the distal breakpoint of C.L. and the proximate boundaries of the GM8785 and GM6803 deletions may contain genetic element(s) that underlie the mental dysfunction of some WAGR patients (Gessler et al. 1989).
A Fetal
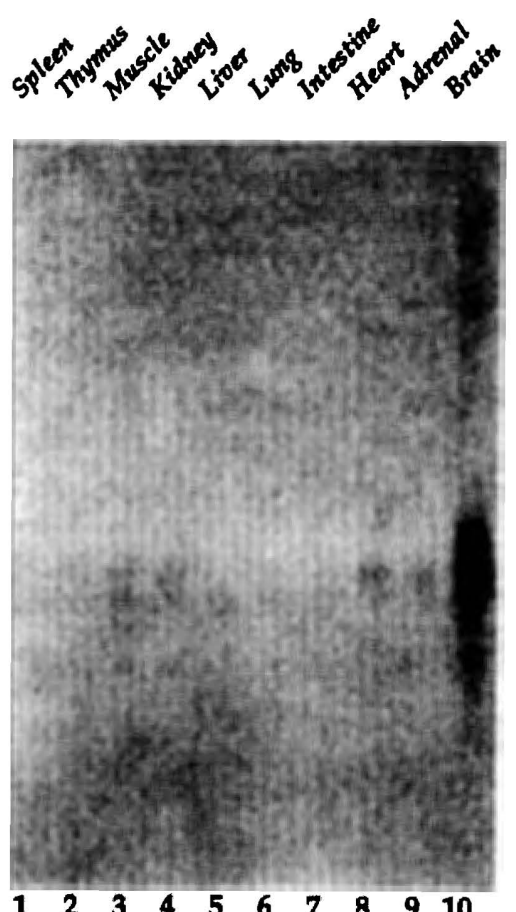

B Adult + Fetal
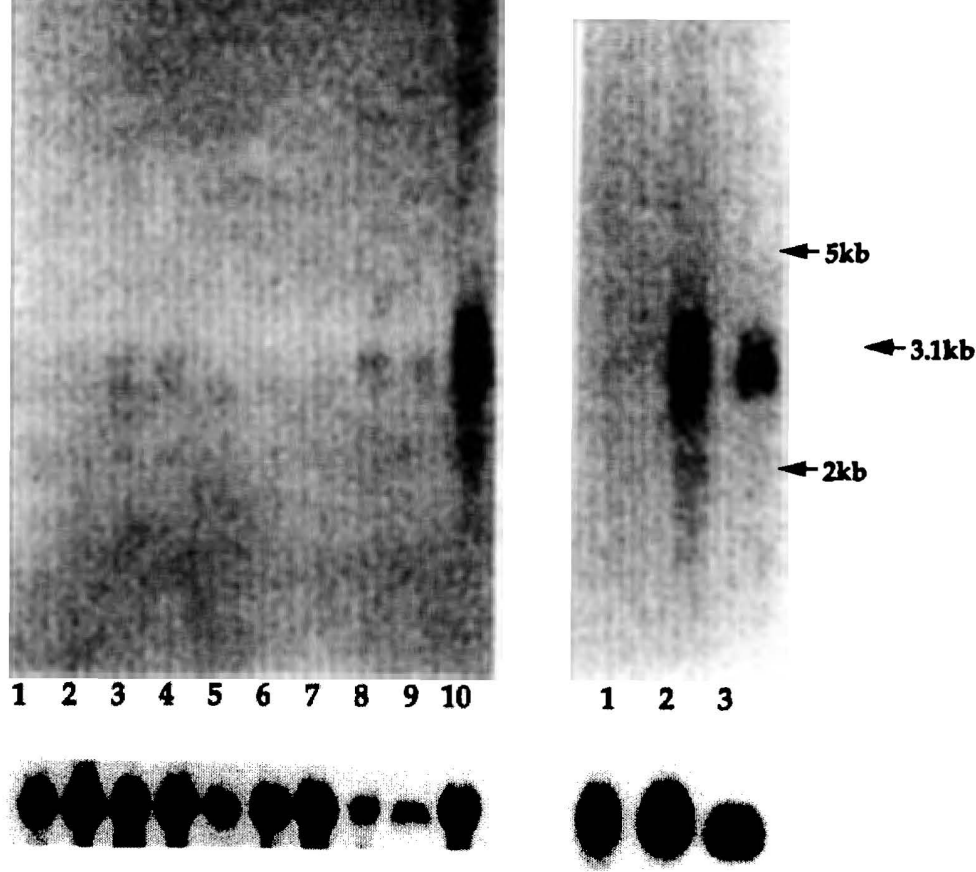


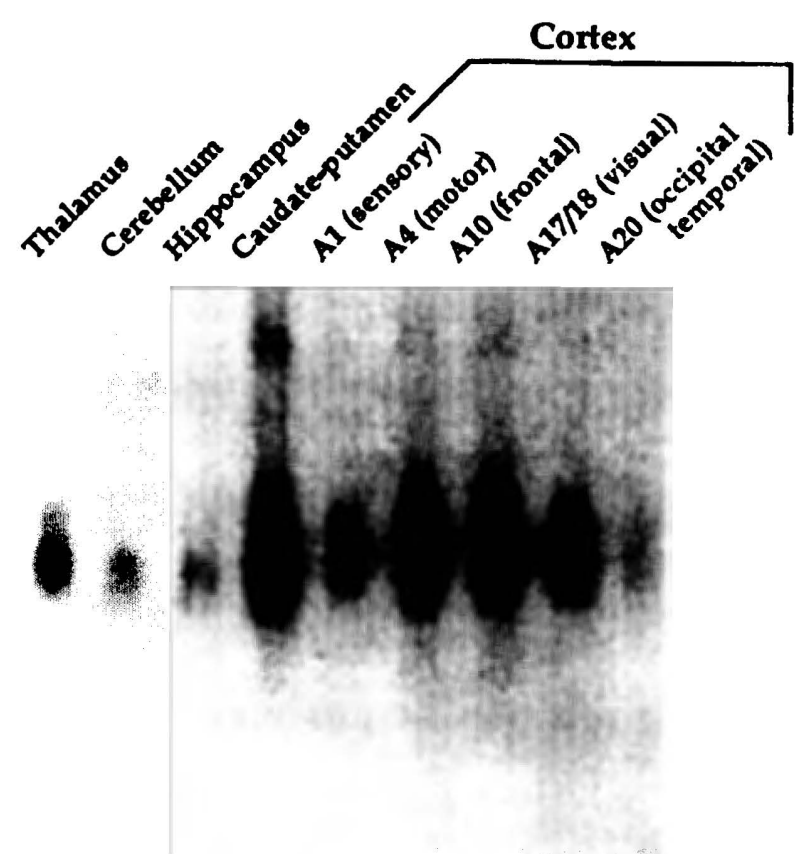

$\begin{array}{lllllllll}1 & 2 & 3 & 4 & 5 & 6 & 7 & 8 & 9\end{array}$

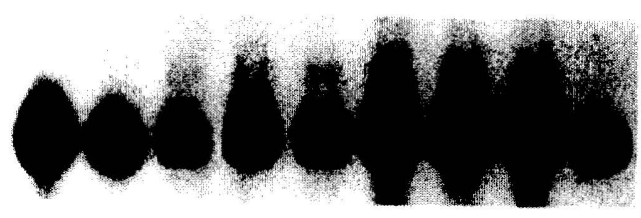

Fig. 6 Expression in brain subregions of a 20 week fetus. Lane 1 thalamus; lane 2 cerebellum; lane 3 hippocampus; lane 4 caudateputamen; lanes 5-9 cortical regions. These are: lane $5 \mathrm{Al}$ (sensory); lane $6 \mathrm{~A} 4$ (motor); lane $7 \mathrm{~A} 10$ (frontal); lane $8 \mathrm{~A} 17 / 18$ (visual); and lane 9 A20 (occipital/temporal). A $10-\mu \mathrm{g}$ sample of total RNA from each subregion was used. The hybridization pattern of the beta actin cDNA control probe is shown below each lane

\section{The cDNA clones from a fetal brain library}

Since D11S302 identified a transcript prominent in brain when hybridized with RNAs from several human fetal tissues (not shown), about $10^{6} \mathrm{pfu}$ of a human fetal brain cDNA library in lambda gt 10 (Feener et al. 1989) were screened with this genomic fragment. Seven phage that hybridized with DIIS302 at high stringency were isolated, six of which were further analyzed. Insert sizes of the cDNA clones ranged from 1.3 to $3.1 \mathrm{~kb}$, with the size of the longest insert similar to that of the 3.1-kb transcript detected on a Northern blot (vida infra). Restriction mapping of the six clones demonstrated that they were all related (not shown).

The cDNA probes used in this report and the clones from which they originated are shown in Fig. 3. The 1.8kb EcoRI fragment (R1.8) from clone c239P-A (Fig. 3B) identifies a number of genomic HindIII fragments ranging in size from 1.1 to $\sim 4.3 \mathrm{~kb}$ (Fig. $3 \mathrm{~A}$, panel 3 ), suggesting that it spans multiple exons. The 3' end of this fragment includes a poly $A$ tract and a polyadenylation signal (in
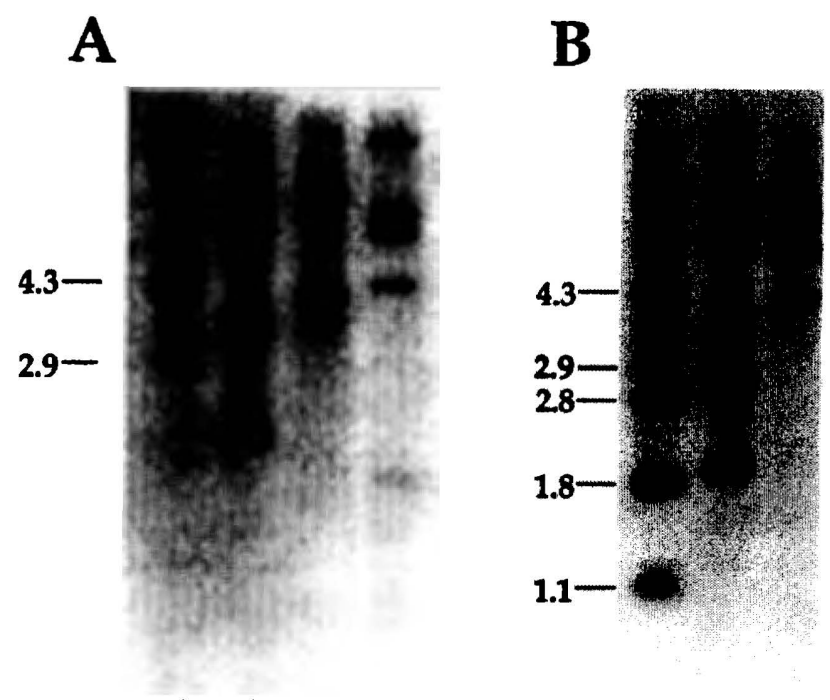

$123 \quad 3 \quad 4$

123

Fig. 7A,B Evolutionary conservation at the DIIS302 locus Cross-hybridization of R0.5b (A) and RI.8 (B) with HindIII-digested human $(I A, I B)$; hamster $(2 A)$; bovine $(3 A, 2 B)$ and chicken $(4 A, 3 B)$ genomic DNAs. Sizes of the human components are indicated. The R0.5b probe is very slightly shorter at the 5 ' end than the R0.5a probe used in Fig. 3A (see Fig. 3B)

preparation). Only two HindIII fragments of $\sim 4.3 \mathrm{~kb}$ and $21 \mathrm{~kb}$ (Fig. 3A, panel 2) are detected in genomic DNA by the 0.5-kb EcoRI fragment (R0.5a). The longer 1.3-kb EcoRI fragment (R1.3) from clone c239P-B identifies the same two fragments and hybridizes weakly with a third large genomic HindIII fragment (Fig. 3A, panel 1).

The chromosome $11 \mathrm{pl} 3$ origin of the cDNA clones identified by D1IS302 was confirmed with somatic cell hybrids (Fig. 4). Three of the four genomic EcoRI fragments $(3.3,1.4$ and $1.3 \mathrm{~kb})$ identified by the $R 1.8$ probe from c239B (lane 1) map to chromosome 11 within the MJ deletion (lanes 3-5). The 4.4-kb EcoRI fragment comigrated with a cross-hybridizing hamster band and could not be mapped with these DNAs. However, this component was present in a human-mouse hybrid with the 11 pter-q23 derivative chromosome (Scott et al. 1979) and only traces of three other chromosomes (lane 5), suggesting that it likely also derives from chromosome 11. The additional bands in lane 5 are murine cross-reacting components. Similarly, both the $4.3-\mathrm{kb}$ and $21-\mathrm{kb}$ HindIII components identified by the R0.5a probe (Fig. 3A, lane 2) uniquely map within the MJ WAGR deletion (not shown).

Northern blot analysis

To determine the tissue distribution of transcription, the cDNA subclones were hybridized with RNAs from a number of human fetal tissues (20 weeks gestation). Expression was prominent in fetal cortex (Fig. 5A) where two mRNA species were observed: an abundant message 
of $\sim 3.1 \mathrm{~kb}$ and an $\sim 3.4-\mathrm{kb}$ transcript of lesser intensity (Fig. 5B, lanes 2, 3). By contrast, neither transcript was observed in the RNA from adult cortex in Fig. 5B, lane 1. Very low levels of expression of one or more RNA species of similar size to the prominent brain transcript were present in the other fetal tissues analyzed.

The subregional pattern of expression of the gene in human fetal brain was analyzed with a panel of RNAs from nine subregions of a 20-week fetus (Fig. 6). The prominent $3.1-\mathrm{kb}$ transcript was expressed at highest levels in the caudate-putamen, motor cortex (A4), frontal cortex (A10) and primary visual cortex $(\mathrm{A} 17,18)$. It was expressed at intermediate levels in the thalamus and at lowest levels in the hippocampus, primary somatosensory cortex (A1) and associative visual cortex (A20). The 3.4$\mathrm{kb}$ transcript was expressed robustly in three of the areas showing good expression of the smaller transcript, caudate-putamen and motor and frontal cortices but was not prominent in primary visual cortex. In frontal cortex, the 3.4-kb transcript was nearly equivalent in intensity to the $3.1-\mathrm{kb}$ message, whereas in motor cortex and caudateputamen the smaller transcript remained predominant. This is more clearly seen on a lighter exposure of the Northern blot. The 3.4-kb transcript was also expressed at low levels in thalamus, primary somatosensory cortex and associative visual cortex. The regional heterogeneity of expression of these mRNAs in the developing fetal brain and the lack of detectable expression in adult cortex suggest a functional specificity of the protein product during brain development.

\section{Evolutionary conservation}

The degree of cross-species hybridization of both D11S302 and the fetal brain cDNA clones identified with this probe is striking. In addition to rodent DNA (Fig. 1), D11S302 hybridized at high stringency with bovine DNA at an intensity comparable to that of human DNA (not shown). Likewise, EcoRI fragments (R0.5b, R1.8) of the cDNA clones identified a number of related sequences in HindIII-digested vertebrate DNAs (Fig.7). The band pattern of both probes with bovine DNA was rather similar to that observed in human DNA, whereas the pattern in chicken DNA was more divergent. Cross hybridization with Drosophila melanogaster DNA was not observed with either probe under the conditions employed.

\section{Discussion}

Recent molecular analysis of the WAGR deletion region has defined two of the genes (Davis et al. 1988) underlying major phenotypic components of the syndrome. The Wilms tumor-1 gene (WT-1; Call et al. 1990; Gessler et al. 1990; Bonetta et al. 1990) encodes a zinc finger transcription factor (Rauscher et al. 1990) important in kidney and the male genitourinary system (Pritchard-Jones et al. 1990; Pelletier et al. 1991; Kreidberg et al. 1993). The aniridia gene PAX-6 (Ton et al. 1991; Jordan et al. 1992) specifies a paired box-domain DNA binding protein implicated in optic cup morphogenesis and craniofacial development (Hill et al. 1991; Glaser et al. 1992). However, little is known about the genetic elements involved in the mental retardation component of the WAGR syndrome.

A genetic origin for the mental impairment in WAGR and AGR patients is suggested by the observation that individuals with larger $11 \mathrm{p}$ deletions are usually retarded, whereas those with smaller deletions have a better prognosis regarding intelligence (Russell and Weisskopf 1986). Cloning of sequences within the WAGR deletion region that are preferentially expressed in fetal brain may therefore identify genes important in the formation of the central nervous system, some of which may also be involved in the mental retardation component of the syndrome.

In addition to the PAX-6 gene, expression of which is restricted to tissues of neural origin, the locus for brainderived neurotrophic factor (BDNF) has recently been mapped within the WAGR deletion region (Hanson et al. 1992). This gene, which specifies a member of the NGF family of neurotrophins implicated in development and maintenance of the nervous system (Barde 1989), is located in a telomeric subregion between FSHB and HVBS1. Although BDNF deletions are not universal in mentally retarded WAGR patients, part of the mental dysfunction in some patients may be attributable to hemizygosity at this locus (Hanson et al. 1992).

Here we describe a highly conserved locus proximal to BDNF, but distal to PAX-6, that is predominantly expressed in fetal brain. The locus maps in proximity, but centromeric to FSHB in the distal part of $11 \mathrm{p} 13$ near the junction of this Giemsa light band with the 1 lp14 Giemsa dark band (Lichter et al. 1990). Partial nucleotide sequence of the corresponding cDNA clones did not show homology to any mammalian sequences currently in GenBank (in preparation). Comparison of the telomeric extent of chromosomal deletions in several individuals with Wilms tumor and aniridia who had normal intelligence with those in patients with the complete WAGR or AGR syndrome had provisionally implicated a deletion subregion around FSHB in part of the mental retardation component of the syndrome (Gessler et al. 1989; Gessler and Bruns 1989b).

Within developing brain, expression of the gene is prominent in frontal, motor and primary visual cortices as well as in the caudate-putamen, with minimal expression in somatosensory and visual associative cortex, the hippocampus and the cerebellum. The hemizygous deletion of this gene in a number of WAGR or AGR patients who are mentally impaired and the lack of deletion of the locus in several patients with normal intelligence (Gessler et al. 1989; Gessler and Bruns 1989b; Junien and McBride 1989), together with the selective and distinctive pattern of expression in fetal brain, raise a possibility of its involvement in mental dysfunction. Since most of the mentally retarded WAGR or AGR patients described in the literature have large deletions that encompass the $11 \mathrm{p} 13$ band and often extend into adjacent $11 \mathrm{p} 12$ and $11 \mathrm{p} 14$ bands, 
this hypothesis cannot be easily tested. However, the extensive evolutionary conservation of the gene should facilitate an evaluation of its role in development of the nervous system in a variety of model organisms.

Acknowledgements This work was supported by $\mathrm{NIH}$ grants HG00186 (G.B.) and NS28965 (R.N.) and a grant from the Deutsche Forschungsgemeinschaft.

\section{References}

Barde Y.A (1989) Trophic factors and neuronal survival. Neuron 2:1525-1534

Bonetta L, Kuehn SE, Huang A, Law DJ, Kalikin LM, Koi M, Reeve AE, Brownstein BH, Yeger H, Williams BRG, Feinberg AP (1990) Wilms tumor locus on 11 p13 defined by multiple CpG islands-associated transcripts. Science 250:994-997

Brunk C, Jones K, James T (1979). Assay for nanogram quantities of DNA in cellular homogenates. Anal Biochem 92:497-500

Call KM, Glaser T, Ito CY, Buckler AJ, Pelletier J, Haber DA, Rose EA, Kral A, Yeger H, Lewis W, Jones C, Housman DE (1990) Isolation and characterization of a zinc finger polypeptide gene at the human chromosome 11 Wilms' tumor locus. Cell 60:509-520

Chirgwin JM, Przybyla AE, MacDonald RJ, Rutter WJ (1979) Isolation of biologically active ribonucleic acid from sources enriched in ribonuclease. Biochemistry 18:5294-5299

Church G, Gilbert W (1984) Genomic sequencing. Proc Natl Acad Sci USA 81:1991-1995

Davis LM. Staliard R. Thomas GH, Coullin P, Junien C, Nowak NJ, Shows TB (1988) Two anonymous DNA segments distinguish the Wilms' tumor and aniridia loci. Science 241:840-842

Feener CA, Koenig M, Kunkel LM (1989) Alternative splicing of human dystrophin mRNA generates isoforms at the carboxy terminus. Nature 338:509-511

Feinberg AP, Vogelstein B (1984) A technique for radiolabelling of DNA restriction endonuclease fragments to high specific activity. Anal Biochem 137:266

Francke U, Holmes LB, Atkins L, Riccardi VM (1979) AniridiaWilms' tumor association: evidence for specific deletions of IIp13. Cytogenet Cell Genet 24:185-192

Gessler M, Bruns GAP (1989a) A physical map around the WAGR complex on the short arm of chromosome 11 . Genomics 5:43-55

Gessler M, Bruns GAP (1989b) A detailed physical map of the WAGR region. Cytogenet Cell Genet 51:1003

Gessler M, Thomas GH, Coullin P, Junien C, McGillivray BC, Hayden M, Jaschek G, Bruns GAP (1989) A deletion map of the WAGR region on chromosome 11. Am I Hum Genet $44: 486-495$

Gessler M, Poustka A, Cavenee W, Neve RL, Orkin SH, Bruns GAP (1990) Homozygous deletion in Wilms' tumours of a zinc-finger gene identified by chromosome jumping. Nature 343:774-778

Glaser T, Walton DS, Maas RL (1992) Genomic structure, evolutionary conservation and aniridia mutations in the human Pax6 gene. Nature Genet 2:232-238
Hanson IM, Seawright A, Heyningen $V$ van (1992) The human BDNF gene maps between FSHB and HVBSI at the boundary of 11p/3-pl4. Genomics 13:1331-1333

Helms CM, Graham JE, Dutchik JE, Olson MV (1985) A new method for purifying lambda DNA from phage lysates. DNA 4:39-49

Hill et al. $1991 \mathrm{n}$

Jordan T, Hanson I, Zaletayev D, Hodgson S, Prosser J. Seawright A. Hastie N, Heyningen $V$ van (1992) The human Pax6 gene is mutated in two patients with aniridia. Nature Genet 1:328-332

Junien C, McBride OW (1989) Report of the committee on the genetic constitution of chromosome 11. Cytogenet Cell Genet 51:226-258

Kreidberg A, Sariola H, Loring J, Maeda M, Pelletier J, Housman D, Jaenisch R (1993) WT-1 is required for early kidney devel. opment. Cell 74:679-691

Lichter P, Tang C-JC, Call K, Hermanson G, Evans GA. Housman D. Ward DC (1990) High-resolution mapping of human chromosome 11 by in situ hybridization with cosmid clones. Science 247:64-69

Neve RL, Harris P, Kosik KS, Kurnit DM, Donlon TA (1986) Identification of CDNA clones for the human microtubule-associated protein tau and chromosomal localization of the genes for tau and microtubule-associated protein 2. Mol Brain Res $1: 27 I-280$

Pelletier J, Bruening W, Li FP, Haber DA, Glaser T, Housman DE (1991) WTI mutations contribute to abnormal genital system development and hereditary Wilms' tumor. Nature $353: 431-434$

Pritchard-Jones K. Fleming S, Davidson D, Bickmore W, Porteous D, Gosden C. Bard J, Buckler A, Pelletier J, Housman D, Heyningen V van, Hastie $N(1990)$ The candidate Wilms' tumor gene is involved in genitourinary development. Nature 346:194-197

Rauscher FJ III, Morris JF, Tournay OE, Cook DM, Curran T (1990) Binding of the Wilms' tumor locus Zinc finger protein to the EGR-1 consensus sequence. Science 250:1259-1262

Riccardi VM, Sujansky E, Smith AC, Franke U (1978) Chromosomal imbalance in the aniridia-Wilms' tumor association: $11 \mathrm{p}$ interstitial deletion. Pediatrics 61:604-610

Russell L, Weisskopf B (1986) Cognition in aniridia-Wilms tumor association: analysis of karyotype association. Am J Hum Genet 39:A78

Sambrook J, Fritsch EF, Maniatis T (1989) Molecular cloning: a laboratory manual, 2nd edn. Cold Spring Harbor Laboratory. Cold Spring Harbor, NY

Schmickel RD (1986) Contiguous gene syndromes: a component of recognizable syndromes. J Pediatr 109:231-24!

Scott AF, Phillips JA, Migeon BR (1979) DNA restriction endonuclease analysis of human $\beta$ - and $\delta$-globin genes on chromosome 11. Proc Natl Acad Sci USA 76:4563-4565

Ton CCT, Hirvonen H, Miwa H, Weil MM, Monaghan P, Jordan $T$, Heyningen $V$ van, Hastie ND, Meijers-Heijboer $H$, Drechsler M, Royer-Pokora B, Collins F. Swaroop A, Strong LC, Saunders GF (1991) Positional cloning and characterization of a paired box-and homeobox-containing gene from the aniridia region. Cell 67:1059-1074 